\title{
THE NEW ANTITRUST POLICY AND THE INDIVIDUAL BUSINESS FIRM ${ }^{\dagger}$
}

\author{
JESSE W. MARKHAM*
}

Probably the most dramatic change of the postwar period in the institutional environment of the business firm is the renewed vigor and vigilance that has been injected into antitrust policy. The change is dramatic in part because it was unexpected: Our federal antitrust policy is our nation's oldest economic policy expressed in public law; the Sherman Act ${ }^{1}$ celebrates its 75 th anniversary in this year of 1965 , its enactment antedating the Federal Reserve $\mathrm{Act}^{2}$ by nearly a quarter century and the 1946 Employment $\mathrm{Act}^{3}$ by well over a half century; throughout much of its history it has scarcely affected the basic practices of business. The trust-busting days of President Theodore Roosevelt, and later of Thurman Arnold, differed from the decade of virtual antitrust suspension in the Ig2os only in the sense that in the former more-but not a great many more-near-monopolies were prosecuted. Accordingly, the business community, the legal profession, economists, even the antitrust agencies themselves, could with reasonable safety assume that antitrust policy now and in the foreseeable future would be approximately what it always had been, a loose prohibition on the possession of-or, more accurately, the flagrant abuse of-undisputed monopoly power and a tight prohibition on price-fixing and related agreements among competitors.

This prohibition left open broad avenues of corporate growth. Until the I940s and the Alcoa decision ${ }^{4}$ there existed virtually no antitrust constraint on internal growth. The firm could not, of course, grow by illegal means such as predatory or discriminatory pricing or other unfair methods of competition, but there was no bar to firm growth by means considered "honestly industrial." Antitrust policy also permitted almost all growth by acquisition short of creating a virtual monopoly; the doctrine enunciated in U.S. Steel $l^{5}$ that "mere size is no offense" not only left the permissible limits of growth by merger at least as high as sixty per cent of the market, it provided an opening for the building of large organizations through the

† Some of the material contained in this essay was presented before the Princeton University-Brookings Institution Round Table on Business-Government Relations, April 17, 1965. The revised essay benefited from the comments of the Round Table participants.

*A.B. I94I, University of Richmond; M.A. 1947, Ph.D. 1949, Harvard University. Professor of Economics, Princeton University. Formerly Chief Economist, Federal Trade Commission. Visiting Ford Foundation Professor at the Harvard Graduate School of Business Administration, 1965-66. Author, The American Economy ( 1963 ). Contributor of articles to economics journals.

126 Stat. 209 (I890), as amended, 15 U.S.C. $\$ \$$ I-7 (1964).

38 Stat. 25 I (1913), 12 U.S.C. \$ 226 (1964).

60 Stat. 23,15 U.S.C. $\$ \$$ I02I-24 (1964).

United States v. Aluminum Co. of America, I48 F.2d 416 (2d Cir. 1945).

E United States v. United States Steel Corp., 251 U.S. 417 (I920). 
conglomerate merger of firms already in possession of larger market shares. ${ }^{6}$ With the Sherman Act prohibiting only a few of the most obvious consolidations for monopoly and the Clayton Act ${ }^{7}$ applicable only to stock acquisitions, firms could grow at will through asset acquisitions and were not seriously limited in their growth through stock acquisitions.

In the predominantly private enterprise market economy of the United States, growth in the economy has been synonymous with business firm growth, both in numbers and in size but principally in size. In the United States the number of firms has shown a remarkable tendency to grow in proportion to the population. In I929 there were twenty-five business firms per 1,000 population, in 1964 there were 25.4. Between 1929 and 1964 while the population was increasing by fifty-seven per cent the number of business firms increased by fifty-nine per cent, but over the same period the Gross National Product (in constant dollars) increased by 187 per cent and per capita GNP nearly doubled. Since per capita GNP doubled while the number of firms per capita remained virtually unchanged, the GNP per firm must have doubled.

This growth in GNP generated per firm can be attributed to the related factors of rising productivity and growth in the size of the average firm through both internal expansion and acquisition. Unfortunately, very little is known about the causal relationship between the growth in GNP and firm size. Conceivably, had firms not doubled their size they may have doubled in number and in this way also have doubled real GNP. Any conclusions on this issue would be highly speculative. The point emphasized here, however, is that growth of the economy in real terms has, in the past, been associated with growth in size of firm.

Moreover, in the process of growing, at least since the turn of the twentieth century, the largest firms individually have tended to grow at a greatly disparate rate, although as a group they have tended to grow in rough proportion to the over-all economy. The work of A. D. H. Kaplan has shown that considerable turnover in rank occurs among the top fifty and the top roo largest American corporations. ${ }^{8}$ For example, of the largest fifty industrial corporations in rgog only thirteen appeared among the largest fifty in Ig60; less than half (twenty-four) of the initial fifty even appeared among the largest noo. Those few that remained among the largest fifty or largest too had, of course, experienced large promotions or demotions in rank. In fact, while much emphasis has been given to the stability of big business in the American economy, only two corporations, United States Steel Corporation and Standard Oil Company of New Jersey (in spite of the latter's major dissolution in I $\left.11^{9}\right)$, have had a long tenure near the top of the list of the largest industrial corporations. ${ }^{10}$

\footnotetext{
${ }^{6}$ United States v. International Harvester Co., 274 U.S. 693 (I927).

7 Ch. 323, $\$ 7,38$ Stat. 73I (1914).

${ }^{8}$ Big Enterprise in a Competitive System 5 (rev. ed. 1963 ).

${ }^{\circ}$ Standard Oil Co. v. United States, 22 I U.S. I (rgIr).

${ }^{10}$ Between 1909 and I960 U.S. Steel's rank gradually declined from first to third, while Standard
} 
While the role mergers have played in company growth, and in the disparate rates of growth among individual firms, is subject to some controversy, there is general agreement that it has been significant. One of the few extensive quantitative studies in this area shows that about eighty large corporations owe from one-third to one-quarter of their size to past mergers and acquisitions; ${ }^{11}$ one distinguished and highly reputable economist in reviewing the study offered persuasive reasons for concluding that the fraction is significantly higher and that "merger has been the basic method by which individual firms have acquired high shares in major industries in the United States."12

Against this background the "new" antitrust policy adds up to a dramatic change in the permissible means of firm growth. The most significant aspects of the new policy are (I) the rapidity with which it has been expanded to encompass business practices heretofore assumed to be the normal and natural modes of business conduct, and (2) the greatly increased vigor with which it has been administered against practices nominally considered of questionable legality but for the most part seldom challenged. Moreover, the new policy, viewed prospectively, has a completely new ingredient. At the same time that both old and recently amended statutes are being administered far more vigorously than at any previous period in history, a concomitant of which is the emergence of several new judicial doctrines every year, congressional committees are introducing new and decidedly more proscriptive legislation in each session of Congress.

Any complete assessment of the impact of antitrust policy on the individual business firm must give consideration to some of these possible new legislative constraints on business conduct as well as the doctrines already laid down in the recent decisions of the Federal Trade Commission and the courts. Even in the unlikely event that none of the bills now pending becomes law, they may very possibly affect the scope and volume of cases brought under existing statutes.

The Statistical Evidence of Intensified Antitrust

While I agree with the statement frequently made by Edward F. Howrey, while he was Chairman of the Federal Trade Commission, that stark numbers are a fatuous means of describing our antitrust policy, trends and sudden changes in such numbers are revealing. The data in table one are indicative of the intensified pace of antitrust in recent years. In the three immediate postwar years $1945-48$ the annual average number of antitrust cases of all kinds initiated by both antitrust agencies and private parties amounted to 196 . For the three-year period $1959-62$ the annual

Oil (New Jersey) rose from second to first. DuPont, only thirtieth on the Igog list, ranked eighth in 1960, and seven of the top ten in 1960 did not appear on the list of the largest fifty in 1909. Some, e.g., General Motors, had not been founded as early as 1909 .

${ }^{11} \mathrm{~J}$. F. Weston, The Role of Mergers in the Growth of Large Firms (1953).

${ }^{23}$ Stigler, The Statistics of Monopoly and Merger, 64 J. Pox. Econ. 33, 40 (1956). 
TABLE I

Antitrust Cases Initiated

\begin{tabular}{|c|c|c|}
\hline Initated by & $\begin{array}{c}\text { Annual Average } \\
1945-1948\end{array}$ & $\begin{array}{c}\text { Annual Averago } \\
1959-1962\end{array}$ \\
\hline 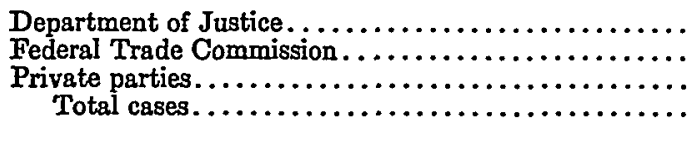 & $\begin{array}{r}36 \\
100 \\
60 \\
196\end{array}$ & $\begin{array}{r}78 \\
600 \\
378 \\
1,056\end{array}$ \\
\hline
\end{tabular}

TABLE 2

The Volume and Disposition of Merger Cases Initiated by the Department of Justice and the Federal Trade Commission, r914-I950 and r951-1964

\begin{tabular}{|c|c|c|c|c|}
\hline \multirow[b]{2}{*}{ Action } & \multicolumn{2}{|c|}{ Department of Justice } & \multicolumn{2}{|c|}{ Federal Trade Commission } \\
\hline & $1914-1950$ & $1951-1964$ & $1914-1950$ & $1951-10 ß 4$ \\
\hline $\begin{array}{l}\text { Total cases initiated } \ldots \ldots \ldots \ldots \ldots \ldots \ldots \ldots \ldots \ldots \ldots \ldots \ldots \ldots \ldots \ldots \\
\text { Dismissed (1) } \ldots \ldots \ldots \ldots \ldots \ldots \ldots\end{array}$ & $\begin{array}{l}20(2) \\
10\end{array}$ & $\begin{array}{l}87 \\
17\end{array}$ & $\begin{array}{l}59 \\
48\end{array}$ & 53 \\
\hline 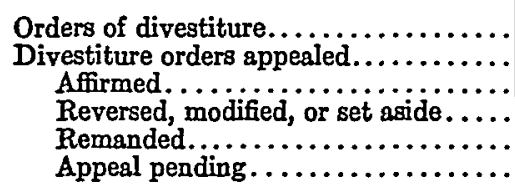 & $\begin{array}{l}\text { 10? } \\
= \\
=\end{array}$ & $\begin{array}{l}40(s) \\
7 \\
\frac{6}{1}\end{array}$ & $\begin{array}{r}11 \\
8 \\
2 \\
6 \\
\\
\end{array}$ & $\begin{array}{l}37(\text { ( ) } \\
14 \\
4 \\
2 \\
2 \\
6 \\
\end{array}$ \\
\hline Initial decision pending. . & - & 30 & - & 9 \\
\hline
\end{tabular}

(1) Includes several cases dismissed by the trial court but on appeal to the Supremo Court.

(2) In 15 of the 20 cases section 7 charges supplemented charges under the Sherman Act or other antitrust statutes.

(3) 8 by consent decrees; 2 by court order after trial.

(4) 49 of the 77 divestitures were obtained through consent orders or decrees; 27 by the Departmont of Justice and 22 by the Federal Trade Commission.

Source: Neither the Federal Trade Commission nor the Department of Justice publighes periodic tabulations of antitrust caseg and their status before the Commission and the courts. I am indebted to Dr. Betty Bock of the National Industrial Confercnco Board for data making this tabulation pessible. Dr. Bock's sources were the mirreographed copics of complaints issued by the Justico Dopartment and mating this tabulation pessible. Dr. Bocks sources were the mirseographed copies of complaints issued by the Jugtice Dopartment and the liederal Trade Commission, and the CCH TrADE $\mathrm{P}$

average number of cases had jumped to 1,056 , or nearly five and one-half times the pre-I949 figure. The largest increases occurred in Federal Trade Commission and private cases, both having registered at least a sixfold increase over the earlier period. Much of the increase in FTC cases is accounted for by the rising volume of Robinson-Patman Act cases, from an annual average of about thirty to an average of nearly 200 between $1945-48$ and $1959-62$, and of unfair competition cases under section 5 of the FTC Act.

In terms of substantive effect on the individual firm, however, the increased volume and broadened scope of merger cases are by far the most important ingredient of the new antitrust policy (table two). Between 1952 and December 3r, 
1964, the Justice Department and the FTC initiated a total of 143 cases, nearly twice the number initiated throughout the entire thirty-six-year period I9I4-50. The average number of merger cases initiated per year has risen from about two to twelve. The antitrust agencies, in sharp contrast with the pre-r950 period, have won the overwhelming majority of their cases, and so far have not lost a single decision in the Supreme Court. It is this last fact, laid against the backdrop of a wide variety of novel theories of competitive injury through merger, that significantly affects the present climate in which the individual firm operates.

A more bizarre but substantively less important aspect of the more intensified antitrust policy is the apparently successful assault being made on secret price-fixing agreements. The public, and especially the business community, will not soon forget the headlined jail sentences imposed in the electrical equipment case. The Justice Department has initiated criminal and civil cases against the West Coast producers of concrete and steel pipe alleging a similar price conspiracy and has cases pending against many of the important steel product lines, such as carbon sheet and steel plates, and against manufacturers of drugs and milled flour. In a case against kosher meat processors selling in the New York metropolitan area the jury, on January 26, 1965, voted for acquittal, but a civil case is still pending.

While these cases, in view of the long-established per se illegality of price-fixing agreements, add no new dimensions to antitrust policy, they are additional evidence of the increased vigor with which the antitrust statutes are now being administered. And the imposition of jail sentences along with the tenfold increase in maximum fines effective since the 1955 Sherman Act amendment ${ }^{13}$ has made a price-fixing arrangement something more than a sporting venture which, if lost, could be financed out of petty cash.

The "new" antitrust policy sketched above has received considerable attention from the business community. It has been prominently placed on the last two programs of the American Bar Association and the last several meetings of the ABA's Section on Antitrust. It has been the topic for four National Industrial Conference Board Special Conferences ${ }^{14}$ and is currently being considered among the most likely economic issues to which the Committee for Economic Development will address one of its forthcoming policy statements. Obviously, any development in the business scene accorded such unprecedented attention merits close and detailed scrutiny.

\footnotetext{
${ }^{13} 69$ Stat. 282 (1955), 15 U.S.C. $\$ \$ I-3$ (I964).

1s The importance the NICB accords the topic is indicated by President $\mathrm{H}$. Bruce Palmer's introductory statement at the Conference on Antitrust in an Expanding Economy: "Existing antitrust legislation, congressional investigations into antitrust matters, and policies and programs of the federal antitrust enforcement agencies have multiplied to the point where they affect virtually every industry and every company." National Industrial Conference Board, The Insact of Antitrust on Economic Growth: Transcript of Special Conference (March 1965).
} 
II

The Specific Components of the New Antitrust Policy

As pointed out earlier, the recently invigorated antitrust policy can be broadly broken down into two components: ( $I$ ) the more effective prosecution of business practices and activities the laws have long prohibited, such as price-fixing agreements and monopolization, and (2) the propagation of essentially new doctrines that now constrain firms from doing what they heretofore could do with impunity and had come to view as "normal" business conduct. It is this latter component that has attracted the greatest attention and generated the most controversy.

In precise terms, what are the once "normal" business practices the new antitrust policy now prohibits? While the individual decisions cover a wide variety of business situations each of which in some respect differs from the others, taken together they reflect the Government's serious concern over the large size of corporations making up the business community and what the Government appears to regard as a corollary, a serious concern over preserving the existing population of small business enterprises. The legality of a business activity is, as will be shown below, no longer determined solely on the basis of its competitive effects-the traditional standard-but may be determined on the basis of how it affects the number, size, and immediate and prospective opportunities of small firms which may be in actual or potential competition with the larger firms involved in the case. ${ }^{16}$

The component of the new antitrust policy is most clearly seen in some of the "recent merger decisions. In the Brown Shoe case, ${ }^{16}$ the Supreme Court held the merger of Brown Shoe, the fourth largest shoe manufacturer with four per cent of total shoe production, and Kinnèy (the desired acquisition), a large family-style shoe retail chain accounting for $x .6$ per cent of retail shoe sales, to be illegal on the grounds that $(x)$ "numerous independent retailers" would be disadvantaged through the economies of production, distribution, and style alterations that strong national chains could effect, and (2) independent shoe manufacturers would be foreclosed from Kinney stores as outlets for their shoes. These particulars were not as important, however, as Chief Justice Warren's statement of what he thought to be the broad purpose of section 7 of the Clayton Act, as amended:17

The dominant theme pervading congressional consideration of the 1950 amendments was a fear of what was considered to be a rising tide of economic concentration in the American economy. ... O Other considerations cited in support of the bill were the desirability of retaining "local control" over industry and the protection of small businesses. ${ }^{18}$

\footnotetext{
${ }^{15}$ Several staff members of the Federal Trade Commission disagree with this broad interpretation of recent decisions, and argue that the protection of small business has not in fact become a consideration. The language used in the decisions cited herein is ambiguous, but the concern with preserving small business is scarcely arguable.

${ }^{10}$ United States v. Brown Shoe Co., 370 U.S. 294 (1962).

${ }^{17} 64$ Stat. II25 (1950), I5 Ú.S.C. $\$ 18$ (1964).

${ }^{18} 370$ U.S. at $315-16$.
} 
One of the very important problems recent merger decisions create for business firms are the multiple and conflicting standards they lay down. Chief Justice Warren, continuing in Brown Shoe, asserted,

It is competition, not competitors, which the [Clayton] Act protects. But we cannot fail to recognize Congress' desire to promote competition through the protection of viable, small, locally owned businesses. Congress appreciated that occasional higher costs and prices might result from the maintenance of fragmented industries and markets. It resolved these competing considerations in favor of decentralization. ${ }^{19}$

As two veteran students of antitrust have remarked,

No matter how many times you read it, that passage states: Although mergers are not rendered unlawful by the mere fact that small independent stores may be adversely affected, we must recognize that mergers are unlawful when small independent stores may be adversely affected. ${ }^{20}$

The decision-making bodies of large business firms may be justifiably perplexed over just exactly what the language of Brown Shoe permits and what it prohibits, but they can scarcely be in doubt as to what the ultimate decision in fact was: A merger that might disadvantage small independent shoe manufacturers or retailers; even if it leads to lower prices and lower costs, violates section 7.

The Federal Trade Commission declared Procter \& Gamble's acquisition of Clorox to be in contravention of Clayton Act section 7 on the grounds that the combination, with Procter \& Gamble's great advertising and capital resources behind the established name of Clorox, would increase its share of the liquid bleach market at the expense of the numerous small liquid bleach producers. ${ }^{21}$

The Federal Trade Commission decided the Foremost Dairies case ${ }^{22}$ on similar grounds. In ordering Foremost to divest itself of dairies it had acquired in ten particular local markets the Commission noted that section 7 "was designed to prevent one company or a group of companies from using mergers to distort irrevocably market structures in small business industries."23 Early in its opinion the Commission conceded that many factors-technological changes, new public health standards, the bonding of milk plants, federal and state market orders, the advantages of "hedging" through expansion into new geographical areas and product lines-all favored the large processor and added up to strong economic incentives for existing firms to grow in size, even to grow by merger. But these market in: centives to grow were subject to the constraining forces of section 7 , and these forces were directed toward the preservation of small business.

\footnotetext{
${ }^{10}$ Id. at 344 .

${ }^{30}$ Bork \& Bowman, The Crisis in Antitrust, 65 Colum. L. Rev. 363, 373 (1965).

31 Procter \& Gamble Co., 3 Trade Reg. Rep. I x6673 (FTC I963).

${ }^{33}$ Foremost Dairies, Inc., 6o F.T.C. 944 (1962).

${ }^{23}$ Id. at 1050 .
} 
A number of recent cases reiterate the doctrine laid down in Brown Shoe, Procter \& Gamble, and Foremost Dairies. Significantly, this doctrine seems to rest far more on the statements of individual senators and congressmen made in the course of floor debates on the Celler-Kefauver Amendment, and on those contained in various reports and studies cired by participants in the debates, than on the language of amended section 7 itself as finally enacted. It is not surprising that more than a modest sprinkling of these statements extol the social beneficence of decentralized industry under "local" ownership, i.e., small business, and that the actual and potential maleficence of industrial concentration, absentee ownership, and oligopoly are all easily equated with big business. Hence, once the Court has accorded such statements the status of competent authority, it has been a relatively easy matter to recompose section 7 as enacted into the less restrictive language of the floor debates.

There has thus emerged the doctrine that even though a given merger may not have demonstrably been shown to have the probable effect of substantially lessening competition, it may by some "ultimate reckoning of social or economic debits and credits" be injurious to "social" competition, to be distinguished from "market" competition. ${ }^{24}$ In two even more recent cases decided by the Supreme Court section 7 was extended in scope to areas hitherto regarded as beyond its reach, as the Court turned aside the "ultimate reckoning" doctrine when made by the defense. In the Philadelphia Nat'l Bank case ${ }^{25}$ the Court extended the jurisdiction of section 7 to include commercial banking. In doing so it also laid down the doctrine that even though a merger might possibly produce a net increase in competition when all markets were considered, it was nevertheless illegal if it tended to lessen competition in one of the relevant markets, sub-markets, or lines of commerce. As Justice Brennan put it, ${ }^{26}$

We are clear, however, that a merger the effect of which "may be substantially to lessen competition" is not saved because, on some ultimate reckoning of social or economic debits and credits, it may be deemed beneficial. A value choice of such magnitude is beyond the ordinary limits of judicial competence ....

It would seem reasonably clear that the Court could find a merger bringing together thirty per cent of a relevant market in contravention of section 7 without referral to the ultimate reckoning doctrine at all. In rejecting it as an inappropriate standard after having resorted to it frequently in immediately preceding cases to support judgments denouncing the merger at hand, and less than a year later going

\footnotetext{
${ }^{24}$ The distinction between the two has been drawn most clearly by James F. Rill, in an as yet unpublished manuscript on "Current Antitrust Law Background."

${ }^{25}$ United States v. Philadelphia Nat'l Bank, 374 U.S. 321 ( ${ }_{96} 63$ ).

${ }^{20} 1 d$. at 37 .
} 
a long way toward returning to it again in Continental $\mathrm{Can}^{27}$ the Court has greatly enlarged the area of potential illegality while substantially reducing the acquiring firm's means of defense. In the recent Penn-Olin case, ${ }^{28}$ the Court extended section 7 to internal growth when accomplished through the instrument of a joint venture. The joint construction of a sodium chlorate plant by Pennsalt Chemical and Olin Mathieson would have been illegal if it had been shown that either joint venturer would have entered the new market independently if the joint venture had not been formed. ${ }^{29}$

The recently enunciated doctrines are not limited to Clayton Act section 7 decisions since these decisions have undoubtedly affected those rendered under the Sherman Act. In United States v. First Nat'l Bank of Lexington, ${ }^{30}$ the Supreme Court found that the merger of two competing banks was itself a violation of section I of the Sherman Act. Indeed, the majority opinion of Justice Douglas goes a long way toward making such mergers per se illegal and having about the same legal status as price-fixing agreements. And in cases brought against American Optical Company and Bausch \& Lomb, Inc., ${ }^{31}$ the Government is entering a prayer that each of the defendants be required to divest itself of all their more than 400 wholesale branches throughout the country and perpetually enjoined from engaging in wholesaling or in business as dispensing opticians. The argument is that these channels of commerce are now "foreclosed" from the independent manufacturers of lenses, frames, and other ophthalmic materials and equipment and that defendants have a competitive advantage over the more than 600 independent wholesale laboratories.

The contrast between these recent antitrust doctrines and that laid down by the Court in the Columbia Steel case ${ }^{32}$ is striking. In that case the Court held that it could not forbid U.S. Steel from accomplishing through acquisition that which it could clearly accomplish legally through internal expansion. The recently enunciated section 7 and Sherman Act doctrines have completely overturned the Columbia doctrine. It is equally obvious that they have completely demolished what the Alcoa decision may possibly have left of the US. Steel doctrine that "mere size is no offense."

\footnotetext{
${ }^{27}$ United States v. Continental Can Co., 378 U.S. 441 (I964). As Justice Harlan warned in his dissent (zd. at 476 ):

"It [the Court] chooses ... to invent a line of commerce the existence of which no one, not even the Government, has imagined; for which businessmen and economists will look in vain; a line of commerce which sprang into existence only when the merger took place and will cease to exist when the merger is undone. I have no idea where $\$ 7$ goes from here, nor will businessmen or the antitrust bar."

${ }^{28}$ United States v. Penn-Olin Chem. Co., 378 U.S. 158 (I964).

${ }^{20}$ United States v. Penn-Olin Chem. Co., 5 Trade Reg. Rep. (1965 Trade Cas.) 171571 (D. Del., Oct. I2, 1965).

30 376 U.S. 665 (1964).

31 United States v. American Optical Co., Civil No. 62-C-206, N.D. Ill., filed Dec. 29, I96r.

${ }^{82}$ United States v. Columbia Steel Co., 334 U.S. 495 (I948).
} 
What current antitrust law administration is leaving relatively untouchedexisting size and market power-has come in for proposed radical remedial action in the form of bills introduced in Congress. In the Eighty-seventh Congress, Congressman Celler introduced H.R. II870, $1187 \mathrm{r}$, and $11872 .{ }^{33}$ These bills define "dominant economic power" to exist when in a line of commerce the four largest firms account for fifty per cent or more of total sales, and make it unlawful to possess or exercise such power when it may tend to lessen competition. H.R. $1 \times 870$ would specifically make it unlawful for any two of the four firms "knowingly to pursue a similar course of action." Also, in the Hearings before the Senate Subcommittee on Antitrust and Monopoly last year, ${ }^{34}$ and which are soon to resume, it is being seriously proposed that the Public Utility Holding Company Act of 1935 or a similar regulation be applied to large industrial firms, the object being to dissolve such firms into independent units having the maximum size consistent with efficiency. And in almost every session of Congress a bill is introduced requiring that parties to all prospective mergers involving firms above a certain size (for example, \$roo million in assets) notify the FTC go days prior to the date of merger and/or seek FTC clearance before they proceed with the merger.

\section{III}

The Impact of the New Antitrust on Business Firms

The foregoing decisions and proposed legislation obviously add up to a substantial change in antitrust policy, a change that holds important implications for corporate enterprise, big and small. It is now perfectly clear that the large corporation, confronting such doctrines as those laid down in Alcoa, Brown Shoe, Procter \& Gamble, Foremost Dairies, Philadelphia Nat'l Bank, and Penn-Olin must carefully select its means of growth. The merger decisions could possibly be turned against almost any expansion by large firms through acquisition, and Alcoa and Penn-Olin limit the means and direction of internal growth. Pending legislation, if enacted, would not only limit much more drastically the growth and size of business firms in the future but would reduce the present size of many large corporations.

In view of the contemporary corporation's propensity to expand through merger it is clear that the newly enunciated doctrines can significantly affect the conduct of corporate affairs. Between $195 \mathrm{r}$ and 196r, the 500 largest industrial firms made 3,404 acquisitions, an average of 6.8 acquisitions per firm. ${ }^{35}$ Between 1948 and 1964, at least 720 manufacturing firms having assets of \$ro million and over, in total

\footnotetext{
${ }^{33} 87^{\text {th }}$ Cong., $2 d$ Sess. (1962).

s"Hearings on Economic Concentration Before the Subcomm. on Antitrust and Monopoly of the Senate Comm. on the Judiciary, 89th Cong., Ist Sess. (1964).

${ }^{35}$ Staff of House Select Committee on Small Business, 87th Cong., 20 Sess., Repont on Mergers and SUperconcentration-Aceuisitions of 500 Largest Industrial and 50 Largest Menchandising Firms 22-23 (Comm. Print I962).
} 
accounting for $\$ 23$ billion in assets, were acquired by other firms. ${ }^{36}$ The assets acquired in the $\$$ Io million-\$25 million asset-size class represented 40.3 per cent of the total manufacturing assets in that size class in I959. The corresponding proportion of total assets acquired through merger for the $\$ 25$ million- $\$ 5^{\circ}$ million class was 38.1 per cent; for the $\$ 5^{\circ}$ million-\$roo million class, 26.7 per cent; for the \$100 million-\$250 million class, 14.2 per cent; and for the over $\$ 25^{\circ}$ million class, 0.5 per cent. ${ }^{37}$ Stated in terms of simple members, every fifteen years or so about onequarter of all the manufacturing firms in the $\$ 5^{\circ}$ million- $\$ 25^{\circ}$ million asset-size class, and nearly half of those falling in the \$ro million-\$50 million asset-size class, are merged with other manufacturing firms. ${ }^{38}$ Merger is clearly a frequent occurrence among corporate enterprise, both as a means of growth and, since for every buyer there is a seller, as a means of terminating independent corporate existence. While these data serve amply to document the fact that industrial mergers still go on apace, they also measure the extent to which corporate enterprise may have to alter their business conduct in the future.

The new antitrust policy is not limited to future acquisitions. As former Assistant Attorney General William Orrick has emphasized, those that have not yet been challenged are subject to being challenged at any future time. As he stated before the Antitrust Section of the ABA in 1964, "Surely there is nothing revolutionary in the concept that earlier acquisitions may be questioned at a much later date." He pointed to Standard $O i^{40}$ and DuPont-General Motors ${ }^{41}$ as examples from the past, and to pending cases against Monsanto, The Blue Chip Stamp Co., Valley National Bank of Arizona, American Smelting and Refining Company, Richfield Oil Company, and the Newmont Mining Corporation as examples in the present. ${ }^{42}$ He could have included on the list the case now pending against General Motors for its acquisition of Euclid in $1953^{43}$ Since it has been calculated that most large corporations owe about one-third of their present size to past acquisitions and mergers, it is clear that such corporations are potentially susceptible to dissolution under section 7 at any time. This vulnerability puts the present-day large

\footnotetext{
${ }^{\text {sa }}$ See testimony of Willard F. Mueller, in Hearings, supra note 34, pt. 2, at 509.

${ }^{37}$ Hearings, supra note 34 , pt. 2 , at 512 .

so Ibid.

${ }^{30}$ Orrick, The Clayton Act: Then and Now (a paper presented at the program of the 1964. Spring meeting, entitled "Fifty Years of the Federal Trade Commission and the Clayton Acts"), 24 ABA Antitrust Section 44,47 (Ig64).

${ }^{10}$ Standard Oil Co. v. United States, 22 I U.S. I (rgII).

11 United States v. E. I. du Pont de Nemours \& Co., 353 U.S. 586 (1957).

43 United States v. Mobay Chem. Co., Civil No. 64-342, W.D. Pa., filed April 14, 1964; United States v. Blue Chip Stamp Co., Civil No. 63-1552S, S.D. Cal., filed Dec. 26, 1963; United States v. Valley Nat'l Bank, Civil No. 4550, D. Ariz., filed Dec. 28, 1962; United States v. American Smelting a Ref. Co., 60 Civil 241, S.D.N.Y., filed Jan. I9, I961; United States v. Richfield Oil Corp., Civil No. 62-1374, S.D. Cal., filed Oct. 9, 1962; United States v. Newmont Mining Corp., Civil No. 4227, S.D.N.Y., filed Dec. $3 r$, 1962 .

${ }^{\$ 3}$ United States v. General Motors Corp., Civil No. I51-370, S.D.N.Y., filed Oct. I6, I959.
} 
corporation in a much different position with respect to antitrust policy than its predecessors.

The most significant impact of the more intensified antitrust policy, however, must probably be measured in terms of its present and future effects on corporate decisions concerning growth rather than in terms of specific acquisitions arrested in specific litigations. Antitrust law, probably more than most law, has its principal effect through compliance. The many open forums of the legal and economics professions dedicated to "the current status of antitrust policy" keep the more alert members of the business community, or at least their legal counsel, well informed on what the statutes proscribe. The legal means of growth are known to have been greatly restricted since the r948 Columbia Steel decision in which the Supreme Court stated that it could not keep U.S. Steel from acquiring through merger that which it was perfectly free to construct for itself. It can be assumed that most large corporations now make expansion plans under the known constraints the new antitrust policy imposes. The fact that the number of cases is still high only reflects the fast moving pace at which the new doctrines have developed; most of the pending cases probably would not have materialized had the decisions on the "deep pocket," "ultimate reckoning," and "foreclosure" doctrines been passed down earlier.

It is now reasonably clear that any horizontal merger involving eight to ten per cent or more of a relevant line of commerce and that any vertical or "conglomerate" acquisition by a large corporation of a small firm having small competitors is highly vulnerable. Former Assistant Attorney General Orrick stated in a speech on May 12, I964, that most important horizontal mergers may now be considered illegal per se. Nor can the acquiring firm sustain its acquisition ( $I$ ) by showing that the net effect of the merger may be to increase competition, even though in a specific more narrowly defined market competition may be lessened; ${ }^{44}$ (2) by showing that the merger permits it more effectively to compete with a larger rival in a "dominant" position; $;^{45}$ or (3) that the merger promotes efficiency and is a normal response to market and technological forces. ${ }^{46}$ It is not as clear what mergers are legal, but presumably mergers among small corporations and vertical and conglomerate acquisitions by firms smaller than most of the acquired firm's rivals avoid most of the recently developed doctrines.

The new doctrines raise important questions of public policy to which there are no obvious answers. Thoughtful scholars and competent students of economic policy have questioned the wisdom of providing aid and protection to small business through the antitrust laws rather than the traditional small business institutions; the wisdom of forbidding cost-reducing and technologically inspired mergers at such

\footnotetext{
it United States v. Philadelphia Nat'l Bank, 374 U.S. 32 (1963).

${ }^{45}$ United States v. Bethlehem Steel Corp., I68 F. Supp. 576 (S.D.N.Y. I958).

${ }^{10}$ United States v. Brown Shoe Co., 370 U.S. 294 (1962); Foremost Dairies, Inc., 60 F.T.C. 944 (I962).
} 
low levels of concentration as were involved in Brown Shoe and Foremost Datries; and the wisdom of choking off so many of the avenues of corporate growth only a short decade ago regarded by the business community as routine.

On the other hand, the new antitrust policy seems to bid fair eventually to reduce the level of over-all concentration as well as the level of concentration in specific lines of commerce; both results have been regarded by many as desirable since the enactment of the Sherman Act-this year celebrating its Diamond Anniversary. But more than this, the new policy will force individual corporations to consider more seriously the alternatives to the acquisition of domestic companies as means of company growth and product diversification. For the large corporation on which antitrust policy has been turned, the logical alternative to such domestic acquisitions is the acquisition of foreign companies, especially in western Europe. In fact, in the six-year period $195^{8-63}$ United States manufacturing corporations established at least 2,200 "new operations" in Europe; since more than three-quarters of the total were located in the European Common Market countries, ${ }^{47}$ they were very likely made in response to the formation of the European Economic Community rather than to the new legal prohibitions on domestic mergers and acquisitions. The total represents a sample of both newly established and acquired facilities. Acquisitions are not shown separately and are not identified by acquiring firms, but the data suggest that the larger United States corporations probably acquired more foreign than domestic firms during this period. Market-extension and product-extension acquisitions in Europe may run counter to the economic objectives of President de Gaulle, but it is doubtful that in the immediate future they will be found in contravention of section 7 .

The more stringent new section $\eta$ doctrines will also require that large corporations substitute new plant construction for some acquisitions they would otherwise make. Indeed, this will very likely be socially the most beneficial effect of the new antitrust policy. Generally, all other things remaining the same, large firms will grow more rapidly when permitted to acquire going establishments than if this avenue of growth is denied them, since product extension through construction of new plants involves greater risks and higher orders of uncertainty than the acquisition of going organizations. On the other hand, new plant construction comprises a net addition to the economy's total productive capacity whereas an acquisition, at least in the initial instance, simply transfers the ownership of existing capacity. However, the ultimate effect of a more stringent ban on acquisition cannot be so easily predicted; when large corporations make acquisitions they generally expand the acquired firm's capacity through new plant construction. Hence, a vigorous antimerger policy encourages the substitution of some new plant construction for acquisition and at the same time discourages new plant additions to acquired firms.

\footnotetext{
${ }^{47}$ The Chase Manhattan Bank, Report on Western Europe, No. 28 (Feb.-March 1964).
} 
The economic calculus is clearly not capable of predicting the economic impact of our new antitrust policy with any high order of precision. The new doctrines have been laid down so rapidly and so recently that they have not perceptibly affected the principal economic indicators to which they are related-not even the indexes of over-all merger activity. Yet it is clear that they hold significant implications for the future conduct of the economic affairs of large corporations and will, unless reversed, force the large multiproduct corporation to explore new alternatives to merger and acquisition. The big issue, of course, is what logically should be the specific objectives of antitrust policy and at what price should they be bought. This question is not likely to be resolved in this the seventy-fifth year of United States antitrust policy—or even by next year. 